\title{
Maternal and paternal effects determine size, growth and performance in larvae of a tropical reef fish
}

\author{
Bridget S. Green ${ }^{1,2 *}$, Mark I. McCormick ${ }^{1}$ \\ ${ }^{1}$ School of Marine Biology and Aquaculture, James Cook University, Townsville, Queensland 4811, Australia \\ ${ }^{2}$ Present address: Howard Marine Sciences Laboratory, Northeast Fisheries Science Center, NOAA Fisheries, \\ 74 Magruder Road, Highlands, New Jersey 07732, USA
}

\begin{abstract}
Larval mortality in marine fishes is strongly linked to individual life history traits such as size and growth, but the processes that influence variability in these traits are poorly understood. We explore the relative importance of maternal and paternal influences and water temperature on the larval growth and performance characteristics of the tropical clownfish Amphiprion melanopus (Pomacentridae). Larvae were reared from an incomplete 4 male $\times 4$ female diallel breeding cross at 2 temperatures $\left(25\right.$ and $\left.28^{\circ} \mathrm{C}\right)$. Paternity interacted with maternity and affected traits immediately prior to and after hatching. Size of larvae at metamorphosis was primarily affected by maternal and paternal influences, but not by rearing temperature. Paternity explained $52 \%$ of the variance in growth rates to metamorphosis, while the combination of paternity, maternity and temperature explained $30 \%$. This strong paternal influence may be due to the extensive role males play in nesttending coupled with the relatively long embryonic duration of the species. A negative relationship between larval growth rate and mortality within a tank emphasised the importance of these parental effects to larval survival and also provides support for the 'bigger is better' hypothesis.
\end{abstract}

KEY WORDS: Larval growth · Maternal effects $\cdot$ Mortality $\cdot$ Paternal effects $\cdot$ Swimming ability · Temperature Resale or republication not permitted without written consent of the publisher

\section{INTRODUCTION}

The population dynamics of marine fishes are characterised by high larval mortality (Ferron \& Leggett 1994), which is predominantly driven by size- and growth-selective processes (Meekan \& Fortier 1996). Size at hatching and pre-settlement growth strongly influence survival before and after settlement (Bergenius et al. 2002, Shima \& Findlay 2002); however, the seminal causes of variation in larval size and growth are poorly understood. Intrinsically, variation in presettlement growth, and the body characteristics that co-vary with growth, are derived from 2 sources: parental influences and environmental fluctuations (Chambers \& Leggett 1996). The interaction between these factors is also likely to be important for larval growth, but has rarely been examined (but see Benoit \& Pepin 1999).
Environmental factors encompass the physical and biotic processes acting on developing eggs and larvae. Condition and growth in fish larvae are influenced by fluctuations in food (Green \& McCormick 1999), temperature (Green \& Fisher 2004), salinity (Sponaugle \& Pinkard 2003), turbidity (Cobcroft et al. 2001), and turbulence (Utne-Palm \& Stiansen 2002). Similarly, the oxygen and temperature environment into which eggs are laid may influence early developmental rates and size at hatching (e.g. Collins \& Nelson 1993, Cancino et al. 2003, Green 2004). As the larva exhausts its yolksac reserves and begins exogenous feeding, water temperature (Houde 1990, Houde \& Zastrow 1993) and the timing of prey production cycles (Cushing 1990) become particularly important determinants of survival. However, in wild fish populations, environmental factors explain less than $40 \%$ of variation in larval growth (Wilson \& Meekan 2002, Caldarone et al. 2003), 
suggesting that other processes, such as parental effects, must account for a substantial amount of variability in growth.

Maternal contributions are generally considered more important than paternal contributions, due to nutritional provisioning of the embryo (Bernado 1996). In fishes, embryo and larval characteristics such as egg size, developmental rate, metabolism, growth and viability are affected by the body condition and genotype of the female parent (Chambers et al. 1989, Chambers \& Leggett 1996, Kerrigan 1997, Marteinsdottir \& Steinarsson 1998). Non-genetic maternal contributions take many forms that directly influence survival probabilities of larvae, including nutritional reserves (Kerrigan 1997), levels of developmental and metabolic hormones (Brown et al. 1988, McCormick 1998, 1999), and parental care (Bernado 1996). While paternal effects have been identified in fishes (Heath et al. 1993, Herbinger et al. 1995, Hoie et al. 1999a, Yamamoto \& Reinhardt 2003), they are not detectable in all larval traits (Hoie et al. 1999b), and are often not considered.

Research on maternal effects in marine fishes has focused on commercially important species, which generally spawn pelagic eggs or benthic eggs without parental care (e.g. Altantic cod Gadus morhua, capelin Mallotus villosus; Chambers \& Leggett 1996). In species that lay benthic eggs, males are generally responsible for nest-tending and nest-site selection (Clutton-Brock 1991). Parental care enhances offspring development (Sargent 1988, 1997), and is therefore a mechanism whereby males can invest in the survival potential of their offspring. Consequently, it is likely that variation in the size and condition of offspring from parentally tended eggs will reflect the male's contribution (Bernado 1996).

The present study experimentally examined the relative importance of paternal, maternal and temperature influences on early life history traits from conception to metamorphosis in a marine fish with paternal egg care. Temperature was selected since it strongly influences metabolism and growth in ectotherms, and the incubation and larval environments can differ markedly in temperature. We employed a diallel breeding design as it allows the variance attributed to the maternal, paternal and temperature components to be partitioned (Heath \& Blouw 1998). Larvae were reared through to metamorphosis under experimental manipulations of parentage and water temperature and their growth and performance were assessed.

\section{MATERIALS AND METHODS}

Study species and brood stock. This study focused on the anemonefish Amphiprion melanopus (Poma- centridae), a common damselfish on coral reefs in the Indo-Pacific. This species was an ideal model for this study as it lays benthic eggs with a relatively long embryonic duration (8 to $9 \mathrm{~d}$, Job \& Bellwood 2000) and exhibits parental egg tending. While nest care involves both parents, males invest more time (40 to $70 \%$ ) in tending embryos than females (20 to $30 \%$ ) (Green 2004).

Brood stock pairs of Amphiprion melanopus were collected by professional aquarium fish collectors from mid-shelf reefs in the northern section of the Great Barrier Reef, adjacent to Cairns $\left(16^{\circ} 8^{\prime} \mathrm{S}, 145^{\circ} 7^{\prime} \mathrm{E}\right)$, where they would naturally experience annual temperature fluctuations from 25 to $30^{\circ} \mathrm{C}$ (see www.aims.gov.au/pages/facilities/weather-stations/ weather-index.html). Pairs were maintained in $100 \mathrm{l}$, round, flow-through tanks at $28^{\circ} \mathrm{C}$ at the James Cook University research aquarium for $2 \mathrm{yr}$ and provided with hollow cement blocks (internal dimensions $16 \times$ $16 \times 19 \mathrm{~cm}$ ) as a nesting substratum, simulating a protected nest. At the commencement of the experiment, adult fish were anaesthetised with clove oil, weighed for wet weight and measured for total length, body depth and body area. A measure of adult condition was estimated by Fulton's $K$ condition factor, i.e. weight $(\mathrm{g}) /$ standard length $(\mathrm{mm})^{3} \times 100$. Sex of each individual was determined by the size of the fish: as a protandrous species, the females are generally considerably larger than the males. This was cross-checked with the shape of the genital papillae, which is short and round in females and long and triangular in males (B. Green pers. obs.). Nesting behaviour and egg-laying was also used to cross-reference sexual identity (Green 2004). We resolved that size was an accurate proxy of sex.

Partitioning maternal, paternal and environmental effects. To test for parental and environmental influences on larvae, we employed a 4 female $\times 4$ male diallel cross, producing 16 clutches from 16 unique parent combinations. A diallel breeding design is powerful in estimating the variation in offspring phenotype due to parental and environmental determinants (Heath \& Blouw 1998). Within a diallel cross design, each female is mated with each male, creating a series of full and half-sibling crosses that replicates clutches produced by each female and by each male. Only 14 clutches were available from the current design because of problems with freezer storage. At the commencement of this experiment, brood stock comprised established breeding pairs, so to avoid effects of pairwise breeding history, each male was moved into a tank with a female that was not previously its breeding partner, commencing with the first cross. Females remained in the same tank and the males were moved for each new mating. Low numbers of sparsely distributed eggs were generally laid in the first clutch from a newly 
matched pair of Amphiprion melanopus (B. Green pers. obs.); therefore, only the second brood from every new mating was sampled. This generally took 4 to $6 \mathrm{wk}$, as $A$. melanopus produce a clutch every $2 \mathrm{wk}$, and new pairs generally took 2 to 4 wk to produce their first clutch.

Each clutch of eggs resulting from the diallel cross was left with the parents until the night of hatching, $8 \mathrm{~d}$ after they were laid. Prior to dusk on the night of hatching, clutches were removed from their natal tank, taken into a temperature-controlled laboratory, photographed under running water and then hatched at dusk in a 701 tank. The hatching tank was a closed system and aeration was used to simulate parental tending, and stimulate hatching (Green \& McCormick 1999).

Temperature manipulation. Immediately after hatching, all larvae from a clutch (between 300 and 700 larvae) were transferred at random into ten $70 \mathrm{l}$ glass aquaria held at $28^{\circ} \mathrm{C}$. The temperature in 5 tanks was gradually adjusted to $25^{\circ} \mathrm{C}$ overnight, following hatching, and 5 tanks were maintained at $28^{\circ} \mathrm{C}$. Through the remainder of the larval phase, 5 tanks were maintained at $28^{\circ} \mathrm{C}$ and 5 tanks at $25^{\circ} \mathrm{C}$ for each experimental clutch, resulting in 10 tanks testing 2 replicate temperatures per clutch. All 14 clutches of larvae resulting from the $4 \times 4$ diallel cross design were divided into the 2 rearing temperatures, with 5 replicate tanks of each in this manner. Differences in larval density within tanks were assumed to be negligible: based on hatchling weight of $0.001 \mathrm{~g}$, the density difference equated to a maximum initial mass difference of $0.006 \mathrm{~g} \mathrm{l}^{-1}$.

Larval rearing. Larvae reared for the temperature manipulation experiment were maintained in 'green water' in an indoor laboratory following the methods of Green \& McCormick (1999), whereby a Nannochloropsis sp. algal culture was added to the tanks each morning. Tanks were lit by fluorescent lights simulating a $14 \mathrm{~h}$ light:10 h dark summer light-cycle, and maintained as a semi-closed system, flushed nightly with temperature controlled water (at either 25 or $28^{\circ} \mathrm{C}$, depending on experimental treatment) when the lights were off. Larvae were fed the rotifer Brachionus sp. at a density of approximately 5 ind. $\mathrm{ml}^{-1}$ for 1 to $3 \mathrm{~d}$ after hatching, and on Day 3 after hatching, Artemia sp. nauplii were added at a concentration of 1 to 2 ind. $\mathrm{ml}^{-1}$ (Green \& McCormick 1999).

Sampling and morphometric measurement. Clutch size and density: Parental influence on clutch dimensions and densities per diallel combination were measured prior to the temperature-manipulation experiment. All egg clutches were photographed prior to hatching, and clutch dimensions were later measured using the UTHSCSA Image Tool graphics package (University of Texas, San Antonio). Egg-clutch area, perimeter and total number of eggs within the clutch were measured. Egg density was calculated as egg density = number of eggs/clutch area.

Egg size: To compare mean egg size between diallel clutches prior to temperature manipulation, 10 eggs from each clutch were sampled immediately prior to hatching and preserved in alcohol. Images of the preserved eggs were made with a digital camera (Olympus DP12) connected to a stereo dissector microscope and egg length, width and area were measured using the UTHSCSA image tool.

Post-hatching larval size: To compare maternal and paternal influences on mean size of newly hatched larvae between diallel clutches prior to temperature manipulation, 10 larvae were left in the hatching tank and maintained at $28^{\circ} \mathrm{C}$ overnight. They were sampled the following morning (1 d after hatching) and preserved in $70 \%$ ethanol for at least 2 mo. Newly hatched larvae were blotted dry with tissue paper, and their wet weight was measured to 3 decimal places. Following this, standard length and total length were measured under a dissecting microscope with a graduated eyepiece.

Size at metamorphosis: Temperature-manipulated rearing experiments were terminated at metamorphosis, when all fish were sampled. Metamorphosis was defined as when more than $70 \%$ of individuals from a tank had their post-orbital white strip and settled to the bottom of the tank (Green \& McCormick 1999, 2001). Fish were preserved and measured for standard length and total length under a dissecting microscope with a graduated eyepiece. Fish were blotted to remove excess water, and their wet weight was measured to 3 decimal places. As growth of Amphiprion melanopus was linear during the larval phase under similar artificial experimental conditions (plotted from Green \& McCormick 2001) growth rates were estimated according to the formula: $R_{\mathrm{g}}=\left(L_{\mathrm{s}}-L_{\mathrm{h}}\right) / T_{\mathrm{s}}$, where $R_{\mathrm{g}}$ is the rate of growth $\left(\mathrm{mm} \mathrm{d}^{-1}\right), L_{\mathrm{s}}$ is the length $(\mathrm{mm})$ at sampling, $L_{\mathrm{h}}$ is the length (mm) at hatching, and $T_{\mathrm{s}}$ is the time (d) from hatching to sampling.

All specimens were preserved in ethanol and treated in the same manner so that any shrinkage due to ethanol storage would be consistent among samples.

Quantifying swimming performance. Critical swimming speed ( $U$-crit, following Brett 1964) was used to determine the effects of rearing temperature and parentage on the functional swimming capabilities of larvae from 8 clutches from the diallel design. $U$-crit is a measure of the maximum sustainable swimming speed of larvae. Temperature affected developmental rate, and the effect of temperature treatment on swimming on absolute versus developmental age has been previously addressed (Green \& Fisher 2004). For the purpose of the current study, swimming measurements were taken for fish of the same developmental age, at 
$7 \mathrm{~d}$ after hatching (dah) for fish reared at $28^{\circ} \mathrm{C}$, and at 11 dah for fish reared at $25^{\circ} \mathrm{C}$. This was an a priori sampling decision to coincide with $1 \mathrm{~d}$ prior to the average time taken to metamorphosis for the $28^{\circ} \mathrm{C}$ and $25^{\circ} \mathrm{C}$ treatments respectively (Green \& Fisher 2004). We measured the swimming speed of 2 fish from each of the 5 replicate tanks at each temperature treatment $\left(25\right.$ and $\left.28^{\circ} \mathrm{C}\right)$, making a total of 10 larvae per clutch at each temperature. Details of all swimming trials are given in Green \& Fisher (2004).
Table 1. Amphiprion melanopus. Correlations (r) of brood stock and egg clutch attributes. No correlations were significant at the Bonferroni corrected $\alpha$-value of $\mathrm{p}<0.007{ }^{*}{ }^{*}$ : significant correlations at $\mathrm{p}<0.05, \mathrm{n}=11$. TL: total length

\begin{tabular}{|lccccr|}
\hline Variable & $\begin{array}{c}\text { No. of } \\
\text { hatchlings }\end{array}$ & $\begin{array}{c}\text { Clutch } \\
\text { perimeter } \\
(\mathrm{mm})\end{array}$ & $\begin{array}{c}\text { Clutch } \\
\text { area } \\
\left(\mathrm{mm}^{2}\right)\end{array}$ & $\begin{array}{c}\text { Egg } \\
\text { count }\end{array}$ & $\begin{array}{r}\text { Egg } \\
\text { density } \\
\left(\mathrm{mm}^{-2}\right)\end{array}$ \\
\hline Female weight & 0.39 & 0.06 & 0.32 & 0.24 & $<0.01$ \\
Female TL & $0.61^{*}$ & 0.23 & 0.49 & $0.68^{*}$ & 0.22 \\
Male TL & -0.40 & 0.33 & 0.09 & -0.19 & -0.43 \\
Male weight & -0.31 & 0.00 & -0.09 & -0.28 & -0.33 \\
Female + male size & 0.20 & 0.41 & 0.45 & 0.40 & -0.13 \\
Female Fulton's $K$ & -0.52 & -0.25 & -0.46 & $-0.69^{*}$ & -0.24 \\
Female + male weight & 0.14 & 0.06 & 0.22 & 0.03 & -0.22 \\
\hline
\end{tabular}

\section{RESULTS}

\section{Parental influence on clutch size and density}

No pre-hatch clutch traits were correlated with parental characteristics at the Bonferroni corrected $\alpha$-value of 0.0071 ; however, at the uncorrected $\alpha$-value of $<0.05$, female total length and Fulton's $K$ correlated with clutch attributes immediately before and after hatching. Female total length was positively correlated with the number of eggs in a clutch and the number of hatchlings, but not with clutch size or dimensions, and Fulton's $K$ was negatively correlated to egg count (Table 1). Male size, and combined female and male size were not correlated with any of these clutch characteristics.

\section{Parental influence on egg size}

A multivariate analysis of variance (MANOVA), exploring trends in the individual egg characteristics (egg length, width and area) simultaneously, showed significant effects of male $\left(F_{8,398}=15.65\right.$, Pillai's trace, $\mathrm{p}<0.001)$, female $\left(F_{4,198}=15.7\right.$, Pillai's trace, $\left.\mathrm{p}<0.001\right)$ and the interaction of male and female $(\mathrm{m} \times \mathrm{f}),\left(F_{20,804}\right.$ $=16.3$, Pillai's trace, $\mathrm{p}<0.001)$ on all 3 egg characteristics. Females produced clutches that differed in mean egg length when mated with different males. Female f3 had the largest eggs when paired with 3 of the 4 males. In contrast, Female f1 produced the smallest eggs when paired with 2 males, but produced some of the largest eggs when paired with Male m1 (Fig. 1A).

\section{Parental influences on larval size}

The standard length of larvae $1 \mathrm{~d}$ after hatching differed when females were mated with different males
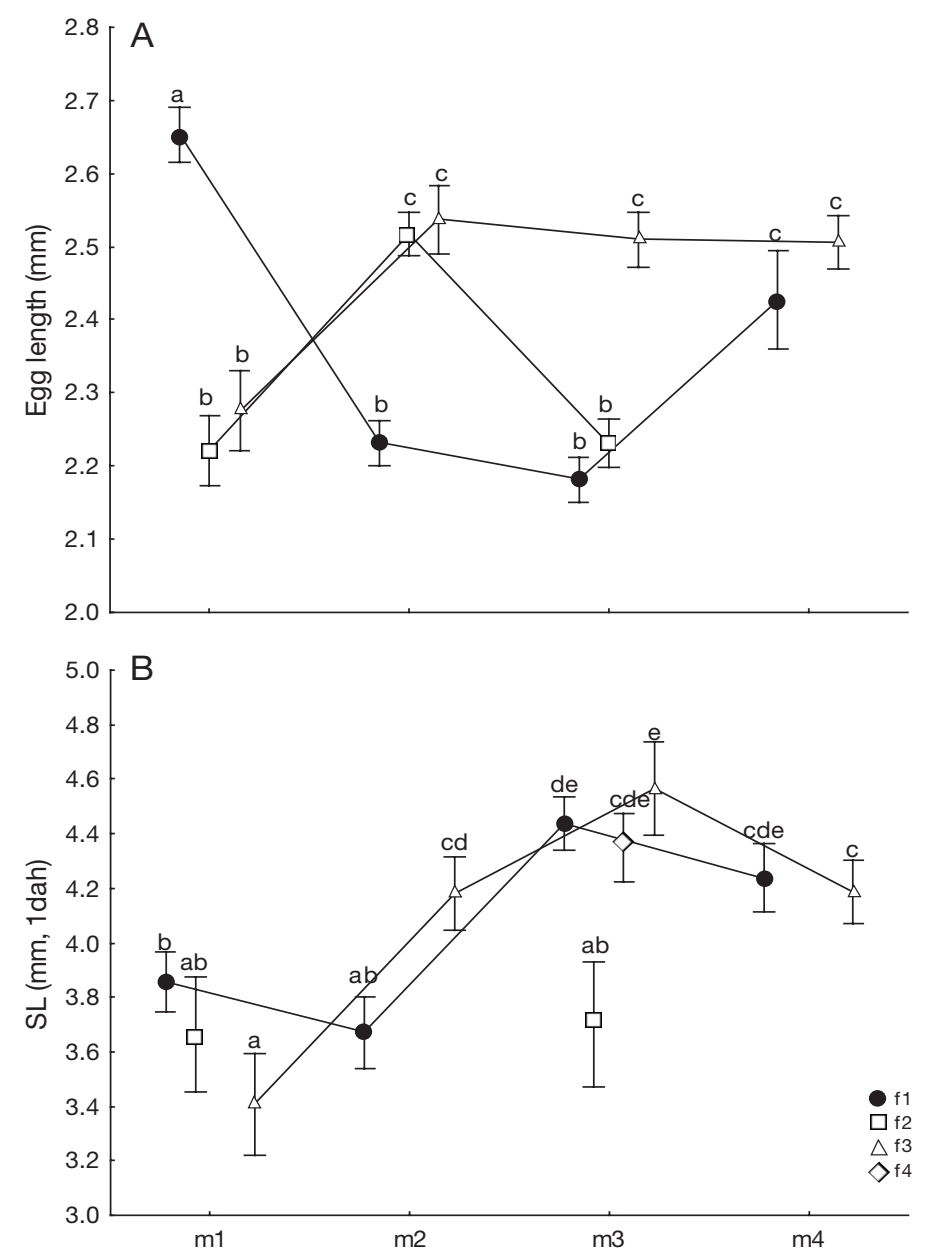

Fig. 1. Amphiprion melanopus. Combined effects of male (m1 to $\mathrm{m} 4$ ) and female (f1 to f4) identity on offspring size. (A) Pre-hatch egg length; (B) standard length (SL) of larvae $1 \mathrm{~d}$ after hatching (dah). Letters above error bars indicate Tukey's HSD (honestly significant difference) homogenous groups $(p<0.05)$. Tukey's HSD identify where differences lie and, as such, each letter represents significantly different subgroup. Error bars are $95 \%$ confidence intervals 
Table 2. Amphiprion melanopus. Comparison of effects of female and male indentity on mean standard length (SL) of offspring $1 \mathrm{~d}$ after hatching: $4 \times 4$ diallel breeding design, using Type IV SS. Significant differences in bold

\begin{tabular}{|lrccc|}
\hline Variable & df & MS & $F$ & $p$ \\
\hline Male & 4 & 1.21 & 2.20 & 0.230 \\
Female & 4 & 1.07 & 0.35 & 0.723 \\
Female $\times$ male & 161 & 0.08 & 15.019 & $<\mathbf{0 . 0 0 1}$ \\
Error & 180 & 0.08 & & \\
\hline
\end{tabular}

(Table 2, Fig. 1B). Sizes of hatchlings from Female f3 were significantly different when she was mated with 3 of the 4 males. Larvae produced by f3 were smallest when sired by Male m1 and largest with Male m3. Hatchlings produced by Female f1 were significantly different between 3 males, while hatchings produced by Female $\mathrm{f} 2$ showed no difference between males. The influence of the male on his offspring differed, depending on the identity of the mated female (Fig. 1B).

\section{Parental and temperature effects on offspring at metamorphosis}

The standard length of larvae at metamorphosis differed as a function of female identity and between the various female/male combinations, while temperature did not have an effect (Table 3, Fig. 2). Larvae from Female f1 were significantly larger at metamorphosis than larvae from Female f2 when both females were crossed with Male m2, but not when crossed with the other males. There were no significant differences in size of larvae at metamorphosis in any larvae from females crossed with Male m4 (Fig. 2).

Table 3. Amphiprion melanopus. Comparison of effects of female and male identity and temperature on standard length and weight measured at metamorphosis of offspring from diallel breeding design. Results of multivariate ANCOVA controlling for time of clutch hatching are given. Significant results in bold

\begin{tabular}{|lrrrrc|}
\hline Variable & $\begin{array}{c}\text { Effect } \\
\text { df }\end{array}$ & $\begin{array}{c}\text { Error } \\
\text { df }\end{array}$ & $\begin{array}{c}\text { Pillai's } \\
\text { trace }\end{array}$ & $F$ & $\mathrm{p}$ \\
\hline Temperature $(T)$ & 2 & 1346 & 0.00 & 0.57 & 0.567 \\
Female & 6 & 2694 & 0.01 & 2.70 & $\mathbf{0 . 0 1 2}$ \\
Male & 6 & 2694 & 0.01 & 1.22 & 0.290 \\
$T \times$ Female & 6 & 2694 & 0.01 & 1.17 & 0.319 \\
$T \times$ Male & 6 & 2694 & 0.01 & 1.57 & 0.151 \\
Female $\times$ Male & 14 & 2694 & 0.02 & 1.74 & $\mathbf{0 . 0 4 2}$ \\
$T \times$ Male $\times$ Female & 14 & 2694 & 0.01 & 1.20 & 0.262 \\
Tank $(T \times$ & 204 & 2694 & 0.16 & 1.13 & 0.109 \\
Male $\times$ Female $)$ & & & & & \\
\hline
\end{tabular}

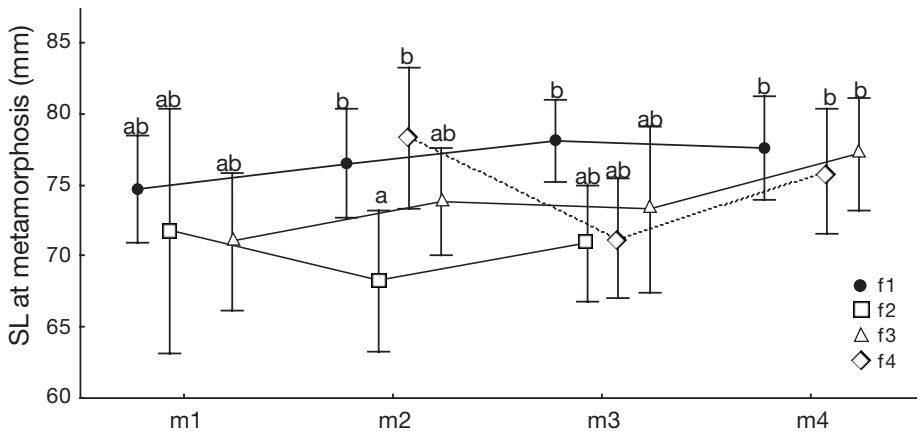

Fig. 2. Amphiprion melanopus. Standard length (SL) of metamorphosed larvae from a $4 \times 4$ diallel cross of males (m1 to $\mathrm{m} 4$ ) and females (f1 to f4). Letters a and b indicate Tukey's homogenous groups $(p<0.05)$. Error bars are $95 \%$ confidence intervals

While larvae raised at the lower temperature $\left(25^{\circ} \mathrm{C}\right)$ metamorphosed at a similar size to larvae raised at ambient temperature $\left(28^{\circ} \mathrm{C}\right)$ (non-significant temperature effects, Table 3), they required more days of development to reach metamorphosis (Fig. 3; temperature $\times$ male $\times$ female $(T \times \mathrm{m} \times \mathrm{f}): F_{7,1348}=4069$, $\mathrm{p}<0.001)$. Time to metamorphosis did not vary in offspring from Females f1 at $28^{\circ} \mathrm{C}$ and $\mathrm{f} 4$ at $25^{\circ} \mathrm{C}$ with all males, while for Female f2, time to metamorphosis varied with all males at $25^{\circ} \mathrm{C}$, and with Males $\mathrm{m} 1$ and $\mathrm{m} 2$ at $28^{\circ} \mathrm{C}$, and Female f3 varied with multiple males at each temperature (Fig. 3). Although there were significant differences as a function of parentage, offspring reared at $25^{\circ} \mathrm{C}$ always took longer to reach metamorphosis than those reared at $28^{\circ} \mathrm{C}$. The mean time to metamorphosis, regardless of parentage, was $8.9 \pm$ $0.06 \mathrm{~d}$ at $28^{\circ} \mathrm{C}$ and $11.6 \pm 0.09 \mathrm{~d}$ at $25^{\circ} \mathrm{C}$.

Individual tanks within temperature treatments and $\mathrm{m} \times \mathrm{f}$ combinations were sampled as units at metamorphosis when at least $70 \%$ of the visible fish had metamorphosed; however, the actual number of fish metamorphosed showed more variability. Temperature did not affect the proportion of fish metamorphosed (temperature: $F_{1,103}=2.515, \mathrm{p}=0.11 ; T \times \mathrm{m} \times \mathrm{f}: F_{7,103}=0.931$, $\mathrm{p}=0.48)$; however, parentage did affect the proportion of fish metamorphosed at the time of sampling (male: $F_{3,103}=4.348, \mathrm{p}<0.05$; female: $F_{3,103}=3.453, \mathrm{p}<0.05$; $\left.\mathrm{m} \times \mathrm{f}: F_{7,103}=3.42, \mathrm{p}<0.05\right)$.

\section{Growth rate and mortality}

Paternity and maternity also influenced the growth rate and mortality of larvae raised at the 2 temperatures (Table 4, Fig. 4). Larval growth rate varied significantly at all levels in a factorial analysis of temperature, female and male identity (Table 4). The combination of 


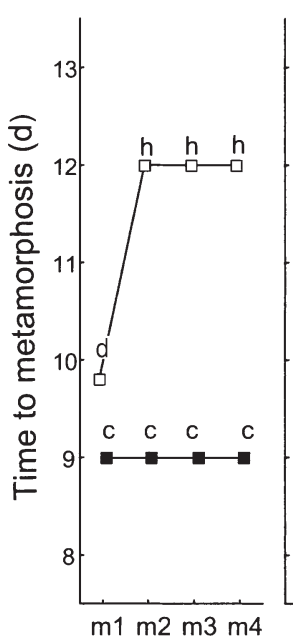

f1

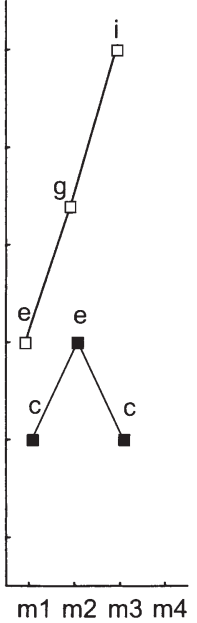

f2

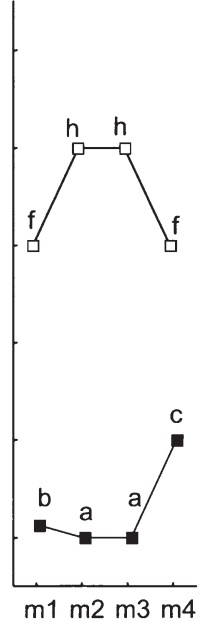

f3

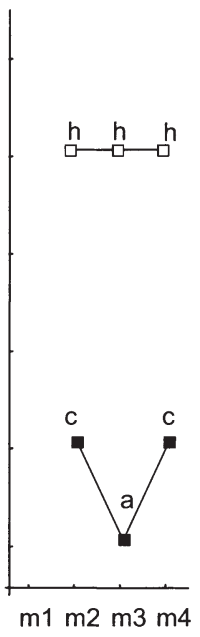

f4
Fig. 3. Amphiprion melanopus. Mean time to metamorphosis of larvae from a 4 female $\times 4$ male diallel cross raised at 25 (口) and $28^{\circ} \mathrm{C}(\boldsymbol{\square})$. Means of 5 replicate tanks per temperature. Letters a to i indicate Tukey's homogenous groups ( $\mathrm{p}<0.05)$; $95 \%$ confidence intervals were included, but are not visible as they are smaller than the data points

these 3 factors accounted for $30 \%$ of the total variability in larval growth rate, while male identity alone accounted for $52 \%$ (Fig. 4A). Growth rates were generally higher at $28^{\circ} \mathrm{C}$ than at $25^{\circ} \mathrm{C}$ (Fig. $4 \mathrm{~A}$ ).

Mortality rates differed as a function of male and female identity, $T \times \mathrm{f}$ and a combination of $T \times \mathrm{f} \times \mathrm{m}$ (Table 4, Fig. 4B). More than $50 \%$ of the variability in

Table 4. Amphiprion melanopus. Mean growth rate and mortality of larvae; full factorial ANOVA of 4 female $\times 4$ male diallel cross raised at 2 temperatures, measured at metamorphosis. Significant results in bold

\begin{tabular}{|lcccc|}
\hline Variable & df & MS & $F$ & $\mathrm{p}$ \\
\hline Growth rate & & & & \\
$\quad$ Temperature $(T)$ & 1 & 0.326 & 582.65 & $\mathbf{< 0 . 0 0 1}$ \\
Female & 3 & 0.002 & 3.36 & $\mathbf{0 . 0 2 3}$ \\
Male & 3 & 0.053 & 96.10 & $\mathbf{< 0 . 0 0 1}$ \\
$T \times$ female & 3 & 0.003 & 4.56 & $\mathbf{< 0 . 0 0 5}$ \\
$T \times$ male & 3 & 0.006 & 10.63 & $\mathbf{< 0 . 0 0 1}$ \\
Female $\times$ male & 4 & 0.003 & 4.46 & $\mathbf{0 . 0 0 2}$ \\
$T \times$ female $\times$ male & 4 & 0.006 & 11.62 & $\mathbf{< 0 . 0 0 1}$ \\
Error & 77 & 0.00056 & & \\
Mortality & & & & \\
Temperature $(T)$ & 1 & 155.1 & 0.32 & 0.572 \\
Female & 3 & 3486.0 & 7.21 & $\mathbf{< 0 . 0 0 1}$ \\
Male & 3 & 1775.4 & 3.67 & $\mathbf{0 . 0 1 5}$ \\
$T \times$ female & 3 & 587.8 & 1.21 & 0.310 \\
$T \times$ male & 3 & 1550.0 & 3.20 & $\mathbf{0 . 0 2 8}$ \\
Female $\times$ male & 4 & 697.4 & 1.44 & 0.228 \\
$T \times$ female $\times$ male & 4 & 1545.9 & 3.19 & $\mathbf{0 . 0 1 7}$ \\
Error & 77 & 483.8 & & \\
\hline
\end{tabular}

mortality was due to differences among replicate tanks, while a further $28 \%$ was attributable to the combination of temperature and male and female identity (Fig. 4B).

Mortality rate within a tank was negatively correlated to growth rate averaged for that tank $(\mathrm{r}=-0.30$, $\mathrm{p}<0.005)$, and there was little change when the effects of temperature were excluded (partial correlation, $\mathrm{r}=-0.29, \mathrm{p}<0.05)$.

\section{Maternal and temperature effects on swimming performance}

Swimming performance, measured as critical swimming ability ( $U$-crit), was affected by rearing temperature and female identity (Table 5, Fig. 5). Differences in the swimming ability of larvae from different females were not directly linked to the size of the female, as larvae from the smallest Female f3 achieved the fastest swimming speeds, while larvae from the medium-sized Female f4 achieved the slowest swimming speeds. However, larvae raised and tested at $28^{\circ} \mathrm{C}$ (ambient temperature) were capable of faster speeds than larvae raised and tested at $25^{\circ} \mathrm{C}$ (Fig. 5).

\section{DISCUSSION}

\section{Maternal and paternal influence on clutch, egg and larval size}

Maternal and paternal effects explained a large proportion of variation in offspring traits in Amphiprion melanopus, from conception to metamorphosis. Maternal influences were apparent in clutch traits prior to hatching, and maternal and paternal traits were impor-

Table 5. Amphiprion melanopus. Comparison of effects of female and male identity and temperature on mean critical swimming performance. (A) Results from full factorial cross; (B) summary of female and temperature effects only. Significant results in bold

\begin{tabular}{|lrccr}
\hline Variable & df & MS & $F$ & p \\
\hline (A) Female & 1 & 343.90 & 11.34 & $<\mathbf{0 . 0 0 1}$ \\
Male & 1 & 0.24 & 0.01 & 0.929 \\
Temperature $(T)$ & 0 & 0 & & \\
Female $\times$ male & 3 & 68.98 & 2.27 & 0.081 \\
Female $\times T$ & 1 & 4.99 & 0.16 & 0.685 \\
Male $\times T$ & 1 & 7.41 & 0.24 & 0.621 \\
Female $\times$ male $\times T$ & 3 & 50.18 & 1.65 & 0.178 \\
Error & 222 & 30.32 & & \\
(B) Female & 2 & 349.93 & 11.28 & $<\mathbf{0 . 0 0 1}$ \\
Temperature $(T)$ & 1 & 661.48 & 21.33 & $<\mathbf{0 . 0 0 1}$ \\
Female $\times T$ & 2 & 17.75 & 0.57 & 0.565 \\
Error & 232 & 31.01 & & \\
\hline
\end{tabular}



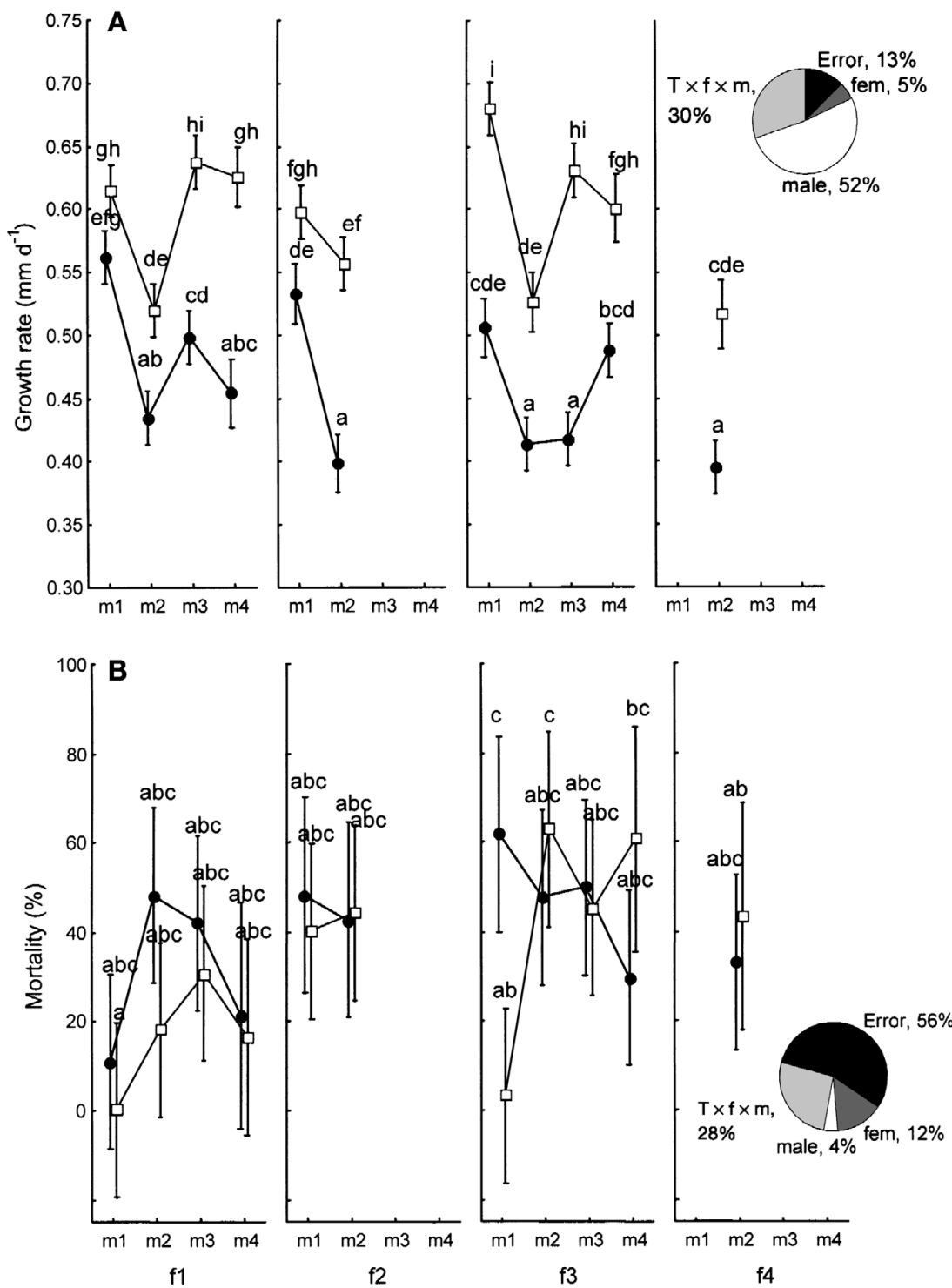

Fig. 4. Amphiprion melanopus. (A) Growth rate and (B) mortality of larvae raised at 2 temperatures $\left(25 \bullet\right.$ and $28^{\circ} \mathrm{C}$ 口) from a 4 female $\times 4$ male diallel cross, determined at metamorphosis. Letters a to i indicate Tukey's homogenous groups $(\mathrm{p}<0.05)$. Error bars are $95 \%$ confidence intervals. Piecharts represent variance components calculated with time of experiment as a covariate; where $T \times \mathrm{m} \times \mathrm{f}$ : interaction temperature $\times$ male $\times$ female, fem: female

tant immediately after hatching through to metamorphosis. Within the 14 clutches resulting from the $4 \times 4$ diallel cross of males and females, clutch size and dimensions were more closely related to characteristics of the female parent than to those of the male; however, males influenced the pre-hatch trait egg size. Interestingly, after hatching, the male $\times$ female interaction became apparent in all larval fish traits measured. This is interesting, as most studies have shown that maternal heritabilities are higher than paternal heritabilities in early life (Heath \& Blouw 1998) — if the sire component is characterised at all (Heyer et al. 2001). However, a strong paternal component is expected in organisms with nest-care behaviour (Bernado 1996).

The important male contribution to early life history traits can be interpreted in the light of the differential parental contributions from conception to hatching in Amphiprion melanopus. The territorial male prepares a nest site, where the female lays a monolayer of between 300 and 700 eggs on the substratum (Allen 1980). The male follows, fertilising the eggs and contributing $50 \%$ of the genetic material, but little else, to the initial egg allocation. A. melanopus has a long embryonic duration compared to many tropical species (i.e. $8 \mathrm{~d}$, compared to $4 \mathrm{~d}$ for other pomacentrids [Job \& Bellwood 2000] and $24 \mathrm{~h}$ for a pelagic spawning serranid [Masuma et al. 1993]) and therefore an extended dependence on maternally derived yolk supply. Consequently, the maternal investment in the endogenous resources of the larvae is high. While male defence and maintenance of the eggs are critical for their survival (Tyler 1995), his nest-care has no detectable effect on clutch size, but may be responsible for the paternal effect apparent in pre-hatch egg size.

Paternal influences were detected in eggs immediately prior to hatching and in newly hatched larvae. As the embryos develop, incorporating the male genetic contribution, the male actively tends them, fanning to oxygenate the eggs, and mouthing to remove dead eggs (Green \& McCormick 2005). The male ensures maintenance of the embryonic environment by keeping the eggs well-oxygenated in a cryptic habitat that typically has poor water flow. He initially spends $40 \%$ of his time tending, increasing this to $70 \%$ towards hatching, compared with only 20 to $30 \%$ time tending by females (Green \& McCormick 2005). Parental care enhances offspring development (Sargent 1988, 1997), and increases the chance of survival in offspring of fishes (Sabat 1994, Kuwamura 1997). Paternal fanning that enhances growth, development and survival, distinguishes Amphiprion melanopus from many of the species commonly targeted for the study of parental effects (e.g. Atlantic cod: Chambers \& Leggett 1996, Marteinsdottir \& Steinarsson 1998). Most studies addressing parental influences that did not detect a paternal effect used fish species that do not display parental care of the eggs, where the opportu- 


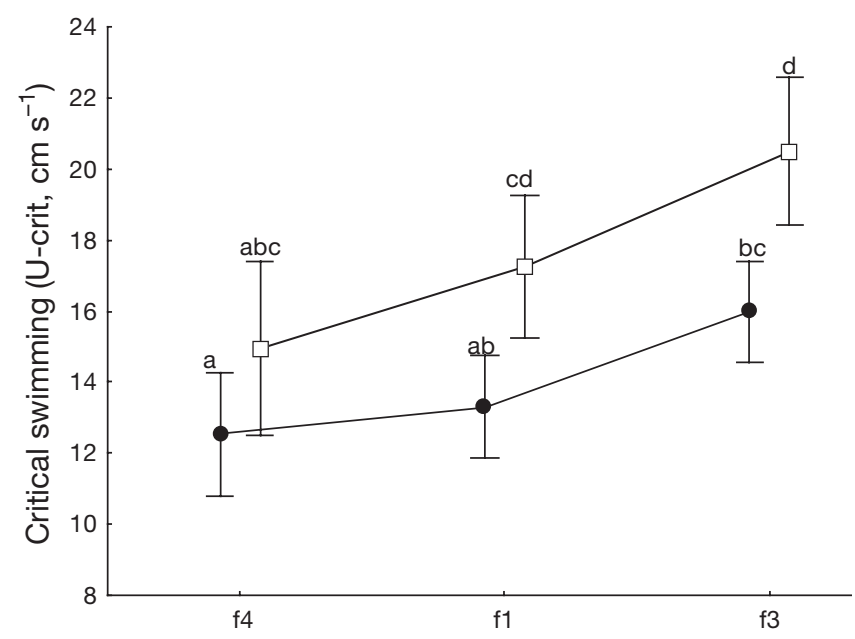

Fig. 5. Amphiprion melanopus. Critical swimming performance of larvae raised at 2 temperatures from 3 females measured $1 \mathrm{~d}$ prior to settlement. Error bars are 95\% confidence intervals. Superscripts ${ }^{a}$ to ${ }^{d}$ indicate Tukey's homogenous groups $(\mathrm{p}<0.05)$. (•) $25^{\circ} \mathrm{C}_{i}(\square) 28^{\circ} \mathrm{C}$

nity for a significant male contribution was restricted (e.g. Benoit \& Pepin 1999). The predominately male tending, coupled with long embryonic duration and ensuing dependence on the maternal contribution, increases the prospect for parental contributions to the larval characteristics of $A$. melanopus.

\section{Temperature effects on larval traits}

Time to metamorphosis

Temperature did not affect size at metamorphosis, but it did affect the time until metamorphosis and also larval growth rates. Amphiprion melanopus larvae raised at $25^{\circ} \mathrm{C}$ (representing the lower limit of their temperature range) metamorphosed at similar sizes to larvae raised at ambient temperature $\left(28^{\circ} \mathrm{C}\right)$; however, fish raised at $25^{\circ} \mathrm{C}$ took longer to reach metamorphosis. The strong influence of water temperature on larval duration rather than size at metamorphosis suggests that metamorphosis is dependent on a size-related threshold rather than age, similar to starry flounder (Policansky 1983), winter flounder (Chambers \& Leggett 1987) and a tropical goatfish (McCormick \& Molony 1995).

Temperature and parental influence on swimming performance

Rearing temperature and maternity each affected maximum sustained swimming speed, while a paternal component was not identified. As the water tempera- ture within the swimming chamber has no detectable influence on swimming speed (Chambers \& Leggett 1996, Green \& Fisher 2004), the reduction in swimming performance with decreased rearing temperature is not explained by the fish's metabolic response to the immediate water temperature. Swimming performance is most probably related to larval body condition, which is a sum of its genotype, modified by environmental history (Brett 1967, Angilletta et al. 2003). In young fishes, environmental effects can significantly modulate the maternal effect, causing variation in traits at the end of the larval period (Chambers \& Leggett 1996).

\section{Growth rate and mortality}

While there were differences in larval growth rate at all levels of the male $\times$ female $\times$ temperature experimental design, the majority of variance in growth rate was attributable to paternity, followed by the interaction of male and female identity and temperature. We found some evidence that initial parental influences are maintained until metamorphosis, by following sibling groups rather than individual growth trajectories. Growth rates were highest in larvae from the Females f1 and f3, which also had the largest eggs and larvae at hatching. These growth rates and sizes identify a maternal and paternal contribution to initial offspring size that is maintained, although in weakened form, throughout the larval period to metamorphosis. The persistence of parentally derived traits throughout larval development is rare, although egg size has predicted larvae and juvenile size (Reznick 1991, Roff 1992, Chambers \& Leggett 1996), and hatching size has predicted juvenile size in wild populations (Vigliola \& Meekan 2002). Generally, environmental variation and favourable conditions after hatching can cause parentally derived growth differences to disappear (De March 1991, Hoie et al. 1999a). While the results from the present study reflect similar significant patterns in wild populations (Vigliola \& Meekan 2002), they should be interpreted carefully due to the small sample size of this diallel design.

The interaction of paternity, maternity and temperature influenced mortality rate and, more importantly, experimental units (tanks) with fast growth had lower mortality than units with slow growth. Such a relationship between growth and survival has been coined the 'bigger is better' hypothesis (Miller et al. 1988, Bailey \& Houde 1989) and is based on the reduced likelihood of predation for bigger individuals. Subsequent support for this hypothesis has shown that fishes that were larger at hatching and had subsequent higher growth, generally survived selective mortality (Anderson 1988, Meekan \& Fortier 1996, Vigliola \& Meekan 2002). Our 
study suggests that there are parental origins for this relationship that may determine survival chances for the offspring in the absence of predators.

More than half of the variability in mortality was attributable to unknown sources among replicate rearing tanks. Contrary to most studies on maternal effects (see Heath \& Blouw 1998 for discussion), there were minimal tank- or rearing-environment effects in the current study, with the exception of mortality. Particular attention was paid to maintaining identical conditions within all rearing units.

This study addressed the 'within population' variability in offspring traits that have maternal and paternal influences, and found significant effects from both these sources for the species Amphiprion melanopus. Maternal effects also exist between populations and between species (Chambers \& Leggett 1996), and therefore it is likely that paternal effects do so also, at least in species with paternal nest-care. To determine the influences of natural variation in recruitment to wild populations, studies of the variation in parental effects between populations is important. Identifying that maternity, paternity and their interaction are critical determinants of larval size and performance is a vital first step in looking for sources of variation in populations that has previously been overlooked as ecological noise.

Acknowledgements. We would like to thank the staff at the James Cook University aquarium facility for their technical assistance, R. Fisher for assistance with the swimming experiments, A. Forrest for assisting with the breeding experiments, J. Eagle and L. Bay and 3 anonymous reviewers for useful comments on the manuscript.

\section{LITERATURE CITED}

Allen GR (1980) The anemonefishes of the world. Species, care and breeding. Aquarium Systems, Mentor, $\mathrm{OH}$

Anderson JT (1988) A review of size dependent survival during pre-recruit stages of fishes in relation to recruitment. J Northw Atl Fish Sci 8:55-66

Angilletta MJ Jr, Wilson RS, Navas CA, James RS (2003) Tradeoffs and the evolution of thermal reaction norms. Trends Ecol Evol 18:234-240

Bailey KM, Houde ED (1989) Predation on eggs and larvae of marine fishes and the recruitment problem. Adv Mar Biol 26:1-83

Benoit H, Pepin P (1999) Interaction of rearing temperature and maternal influence on egg development rates and larval size at hatch in yellowtail flounder (Pleuronectes ferrugineus). Can J Fish Aquat Sci 56:785-794

Bergenius MAJ, Meekan MG, Robertson DR, McCormick MI (2002) Larval growth predicts the recruitment success of a coral reef fish. Oecologia 131:521-525

Bernado JH (1996) Maternal effects in animal ecology. Am Zool 36:83-105

Brett JR (1964) The respiratory metabolism and swimming performance of young sockeye salmon. J Fish Res Board Can 21:1183-1226
Brett JR (1967) Swimming performance of sockeye salmon (Oncorhynchus nerka) in relation to fatigue time and temperature. J Fish Res Board Can 24:1731-1741

Brown CL, Doroshov SI, Nunez JM, Haley C, Vaneenennaam J, Nishioka RS, Bern HA (1988) Maternal triiodothyronine injections cause increases in swimbladder inflation and survival rates in larval striped bass, Morone saxatilis. J Exp Zool 248:168-176

Caldarone EM, Onge-Burns JMS, Buckley LJ (2003) Relationship of RNA/DNA ratio and temperature to growth in larvae of Atlantic cod Gadus morhua. Mar Ecol Prog Ser 262: $229-240$

Cancino JM, Gallardo JA, Torres FA (2003) Combined effects of dissolved oxygen concentration and water temperature on embryonic development and larval shell secretion in the marine snail Chorus giganteus (Gastropoda: Muricidae). Mar Biol 142:133-139

Chambers RC, Leggett WC (1987) Size and age at metamorphosis in marine fishes: an analysis of laboratory-reared winter flounder (Pseudopleuronectes americanus) with a review of variation in other species. Can J Fish Aquat Sci 44:1936-1947

Chambers RC, Leggett WC (1996) Maternal influences on variation in egg sizes in temperate marine fishes. Am Zool 36:180-196

Chambers RC, Leggett WC, Brown JA (1989) Egg size, female effects, and the correlation between early life history traits of capelin, Mallotus villosus: an appraisal at the individual level. Fish Bull US 87:515-523

Clutton-Brock TH (1991) The evolution of parental care. Princeton University Press, Princeton, NJ

Cobcroft JM, Pankhurst PM, Hart PR, Battaglene SC (2001) The effects of light intensity and algae-induced turbidity on feeding behaviour of larval striped trumpeter. J Fish Biol 59:1181-1197

Collins L, Nelson S (1993) Effects of temperature on oxygen consumption, growth, and development of embryos and yolk-sac larvae of Siganus randalli (Pisces: Siganidae). Mar Biol 117:195-204

Cushing DH (1990) Plankton production and year-class strength in fish populations: an update of the match/ mismatch hypothesis. Adv Mar Biol 26:249-293

De March BGE (1991) Genetic, maternal and tank determinants of growth in hatchery-reared juvenile Artic charr (Salvelinus alpinus). Can J Zool 69:655-660

Ferron A, Leggett WC (1994) An appraisal of condition measures for marine fish larvae. Adv Mar Biol 30:217-303

Green BS (2004) Parental and environmental effects on the early life history of a tropical reef fish, Amphiprion melanopus. PhD thesis, James Cook University, Townsville

Green BS, Fisher R (2004) Temperature influences swimming speed, growth and larval duration in coral reef fish larvae. J Exp Mar Biol Ecol 299:115-132

Green BS, McCormick MI (1999) Influence of larval feeding history on the body condition of Amphiprion melanopus. J Fish Biol 55:1273-1289

Green BS, McCormick MI (2001) Ontogeny of the digestive and feeding systems in the anemonefish Amphiprion melanopus. Environ Biol Fish 61:73-83

Green BS, McCormick MI (2005) $\mathrm{O}_{2}$ replenishment to fish nests: males adjust brood care to ambient conditions and brood development. Behav Ecol 16:389-397

Heath DD, Blouw DM (1998) Are maternal effects in fish adaptive or merely physiological side effects? In: Mouseau TA, Fox CW (eds) Maternal effects as adaptations. Oxford University Press, New York, p 178-201

Heath DD, Bernier NJ, Heath JW, Iwama GK (1993) Genetic, 
environmental and interaction effects of growth and stress response of Chinook salmon (Oncorhynchus tshawytscha) fry. Can J Fish Aquat Sci 50:435-442

Herbinger C, Doyle R, Pitman E, Paquet D, Mesa K, Morris D, Wright J, Cook D (1995) DNA fingerprint based analysis of paternal and maternal effects on offspring growth and survival in communally reared rainbow trout. Aquaculture $137: 245-256$

Heyer CJ, Miller TJ, Binkowski FP, Caldarone EM, Rice JA (2001) Maternal effects as a recruitment mechanism in Lake Michigan yellow perch (Perca flavescens). Can J Fish Aquat Sci 58:1477-1487

Hoie H, Folkvord A, Johannessen A (1999a) The influence of different parental combinations and incubation temperature on the RNA and DNA content of herring larvae at hatching: a pilot study. J Fish Biol 55:110-118

Hoie H, Folkvord A, Johannessen A (1999b) Maternal, paternal and temperature effects on otolith size of young herring (Clupea harengus L.) larvae. J Exp Mar Biol Ecol 234: 167-184

Houde ED (1990) Temperature-dependent and size-dependent variability in vital rates of marine fish larvae. In: ICES Council meeting 1990 (Collected papers), International Council for the Exploration of the Sea, Copenhagen

Houde ED, Zastrow CE (1993) Ecosystem- and taxon-specific dynamic and energetic properties of larval fish assemblages. Bull Mar Sci 53:290-335

Job SD, Bellwood DR (2000) Light sensitivity in larval fishes: implications for vertical zonation in the pelagic zone. Limnol Oceanogr 45:362-371

Kerrigan BA (1997) Variability in larval development of a tropical reef fish (Pomacentridae: Pomacentrus amboinensis): the parental legacy. Mar Biol 127:395-402

Kuwamura T (1997) Evolution of female egg care in haremic triggerfish, Rhinecanthus aculeatus. Ethology 103: 1015-1023

Marteinsdottir G, Steinarsson A (1998) Maternal influence on the size and viability of Iceland cod Gadus morhua eggs and larvae. J Fish Biol 52:1241-1258

Masuma S, Tezuka N, Teruya K (1993) Embryonic and morphological development of larval and juvenile coral trout, Plectropomas leopardus. Jpn J Ichthyol 40:333-342

McCormick MI (1998) Behaviourally induced maternal stress in a fish influences progeny quality by a hormonal mechanism. Ecology 79:1873-1883

McCormick MI (1999) Experimental test of the effect of maternal hormones on larval quality of a coral reef fish. Oecologia 118:412-422

Editorial responsibility: Otto Kinne (Editor-in-Chief), Oldendorf/Luhe, Germany
McCormick MI, Molony BW (1995) Influence of water temperature during the larval stage on size, age and body condition of a tropical reef fish at settlement. Mar Ecol Prog Ser 118:59-68

Meekan M, Fortier L (1996) Selection for fast growth during the larval life of Atlantic cod Gadus morhua on the Scotian Shelf. Mar Ecol Prog Ser 137:25-37

Miller TJ, Crowder LB, Rice JA, Marschall EA (1988) Larval size and recruitment mechanisms in fishes: toward a conceptual framework. Can J Fish Aquat Sci 45: $1657-1670$

Policansky D (1983) Size, age and demography of metamorphosis and sexual maturation in fishes. Am Zool 23:57-63

Reznick DN (1991) Maternal effects in fish life histories. In: Dudley E (ed) Evolutionary biology. Discorides Press, Portland, OR, p 780-793

Roff DA (1992) The evolution of life histories: theory and analysis. Chapman \& Hall, New York

Sabat A (1994) Costs and benefits of parental effort in a brood-guarding fish (Ambloplites rupestris, Centrarchidae). Behav Ecol Sociobiol 5:195-210

Sargent R (1988) Paternal care and egg survival both increase with clutch size in the fathead minnow, Pimephales promelas. Behav Ecol Sociobiol 23:33-37

Sargent R (1997) Parental care. In: Godin JGJ (ed) Behavioural ecology of teleost fishes. Oxford University Press, Oxford, p 292-315

Shima JS, Findlay AM (2002) Pelagic larval growth rate impacts benthic settlement and survival of a temperate reef fish. Mar Ecol Prog Ser 235:303-309

Sponaugle S, Pinkard D (2003) Impact of variable pelagic environments on natural larval growth and recruitment of a reef fish. J Fish Biol 64:34-54

Tyler WA (1995) The adaptive significance of colonial nesting in a coral-reef fish. Anim Behav 49:949-966

Utne-Palm A, Stiansen J (2002) Effect of larval ontogeny, turbulence and light on prey attack rate and swimming activity in herring larvae. J Exp Mar Biol Ecol 268:147-170

Vigliola L, Meekan MG (2002) Size at hatching and planktonic growth determine post-settlement survivorship of a coral reef fish. Oecologia 131:89-93

Wilson D, Meekan MG (2002) Growth-related advantages for survival to the point of replenishment in the coral reef fish Stegastes partitus (Pomacentridae). Mar Ecol Prog Ser 231:247-260

Yamamoto TR, Reinhardt UG (2003) Paternal effect on otolith size at emergence in masu salmon. J Fish Biol 62: $1226-1231$

Submitted: February 24, 2004; Accepted: October 12, 2004 Proofs received from author(s): February 21, 2005 